Бюро демократичних інститутів та прав людини ОБСЄ. Варшава, $2019.57 \mathrm{c}$.

2. Національний екзит-пол'2004. К.: Центр «Демократичні ініціативи», 2005. $196 \mathrm{c.}$

3. Нестерович В.Ф. Виборче право України: Підручник. Київ: Видавництво Ліра-К, 2017. 504 с.

4. Афанасьєва М. В. Виборча інженерія в Україні: монографія. Одеса: Юридична література, 2014. 384 с.

5. Федоренко В.Л. Запровадження окремих міжнародних стандартів виборчого права в контексті модернізації Конституції України. Бюлетень Міністерства юстииії України. 2013. № 12. C. $12-19$.

\title{
DOI https://doi.org/10.30525/978-9934-26-116-9-7
}

\section{КОНСТИТУЦІЙНА РЕГЛАМЕНТАЦІЯ СТАТУСУ ВИЩОЇ РАДИ ПРАВОСУДДЯ ТА ВІДПОВІДНИХ ОРГАНІВ У ЗАРУБІЖНИХ КРАЇНАХ ЯК ОСНОВА ЇХ НЕЗАЛЕЖНОСТІ}

\author{
Халюк С. O. \\ кандидат юридичних наук, дочент, \\ дочент кафедри конституиійного права та прав людини \\ Національної академії внутрішніх справ \\ м. Київ, Україна
}

В умовах сьогодення ефективна діяльність судової влади $є$ ключовою передумовою сталого демократичного розвитку держави. Адже процеси державного регулювання та правових взаємовідносин, які утворюються між дотичними до них суб'єктами у значній мірі знаходять своє відображення у повсякденній діяльності суддівського корпусу уповноваженого на прийняття рішень у тих чи інших спорах. А тому, завдання судової гілки влади полягає не тільки у здійсненні правосуддя та конституційному нагляді, але і у постійних узгоджених діях з іншими органами влади по вдосконаленню правових інструментів, що регулюють діяльність як державного апарату, так і суддівського корпусу зокрема. Саме тому кожна країна світу намагається розробити не лише вдалі закони, але й налагодити роботу суддівського корпусу, представники якого ці закони будуть застосовувати. 
Україна стала на шлях утвердження Вищої ради правосуддя як органу, що має конституційний статус лише в пострадянський період. В цей період відбувається легальне оформлення інституційних основ судової влади і правового статусу ii носіїв, закріплення гарантій їх незалежності і самостійності суддів. Базові засади незалежності суддівського корпусу в частині його формування та функціонування, які безпосередньо стосуються добору кандидатів на посади суддів, їх призначення та звільнення 3 посад закладені 3 урахуванням низки міжнародних актів та відповідного зарубіжного досвіду.

Саме міжнародні акти та національне законодавство окремих країн Європейського Союзу дозволяють у повній мірі виокремити загальні та специфічні риси конституційної регламентації та статусу відповідних органів і запропонувати шляхи вдосконалення роботи як Вищої ради правосуддя, так і судової системи України в цілому.

Так, Рекомендація CM/Rec (2010) 12 Комітету Міністрів Ради Свропи державам-членам «Щодо суддів: незалежність, ефективність та обов'язки» від 17 листопада 2010 року містить норму, передбачає в контексті забезпечення незалежності суддів передбачити утворення Ради суддів відповідно до закону або конституції, що прагне зберегти незалежність суддів та судової влади загалом i, таким чином, сприяти ефективному функціонуванню судової системи (п. 26) [1].

Аналогічні до Вищої ради правосуддя України органи є в багатьох країнах Європи: у Франції, Італії, Молдові, Португалії - це Вища рада магістратури; у Албанії, Андоррі, Вірменії, Бельгії, Грузії - Вища рада юстиції (правосуддя); у Польщі - Національна Рада Судівництва; Судова рада - Словенія, Словаччина; в Іспанії - Генеральна рада судової влади, у Болгарії - Вища судова рада, у Колумбії - Вища рада судової влади, у Сербії та Казахстані - Вища судова рада, в Угорщині Національна рада юстиції, у Турецькій Республіці - Вища рада суддів і прокурорів; у Хорватії - Державне судове віче тощо.

Загалом, в результаті системного аналізу конституцій та профільного законодавства країн світу можна виокремити такі тенденції. По-перше, метою створення цих органів $є$ підтримка необхідного балансу між незалежністю судової влади, з одного боку, і можливістю здійснення громадського контролю за ії діяльністю - з іншого. А тому, основним завданням утворення та функціонування судових рад стала необхідність дотримання принципу незалежності судової влади. Цей принцип $є$ ключовим елементом правопорядку всіх демократичних держав, що визначає місце суду в системі державної влади та будується на основі принципу поділу влад. Саме за таких умов Вища рада правосуддя та відповідні органи в зарубіжних країнах покликані стати 
необхідними інструментами для забезпечення незалежності судової влади в цілому. А по-друге, фактичним наслідком закріплення принципів поділу влад та незалежності судової влади стало утворення особливих судових органів (судових рад), які представляючи судову владу, участі в здійсненні правосуддя не беруть. Показово, що більшість новітніх конституцій демократичних держав Центральної і Східної Свропи містить норми, якими регламентується правовий статус вказаних органів. А тому процес «конституційності» правового статусу даних органів має тенденцію до поширення, і така тенденція поступово стає глобальною.

Ще один аспект про який варто зауважити в продовження викладу попередніх узагальнень. Аналіз конституцій зарубіжних країн дає можливість виокремити два основні способи регламентації правового статусу розглядуваних нами Рад. До першої групи можна віднести країни $\epsilon$ розширеною конституційної регламентацією правового статусу відповідних судових рад. Йдеться, зокрема про такі країн, наприклад, як Бельгія (ст. 151), Греція (ст. 88), Словацька Республіка (ст. 141a), Туреччина (ст. 159), Франції (ст. 65), Молдова (ст. 122-123), Македонія (ст. 104-105), Кіпр (ст. 157), Італія (ст. 104-105). В конституціях цих країн достатньо грунтовно визначається статус відповідних органів, який може включати місце та роль у судовій системі, сукупність повноважень, склад, строки повноважень, відповідальність членів судових рад та інші складові їх статусу.

До іншої групи можна віднести конституції країн, де вкрай лаконічно визначено правовий статус розглядуваних судових рад. Це конституції таких країн як Румунія (ст. 132), Словенія (ст. 131), Хорватія (ст. 121), Португалія (ст. 218), Польща (ст. 186-187), Іспанія (ст. 122.1) та деякі інші.

Отже, 3 огляду на вищевикладене, а також враховуючи сучасні політико-правові процеси, що мають місце у судовій сфері, достатня незалежність зазначених судових рад повинна бути закріплена на законодавчому рівні: або в конституції, або у відповідному законі. Відсутність згадки в конституції країни про ті чи інші елементи статусу розглядуваних рад має неоднозначне сприйняття. Адже регламентація статусу на рівні закону призводить до більшої гнучкості та оперативності внесення законодавчих змін за потреби. В той же час деталізація статусу на рівні конституції посилює гарантії згаданого вище статусу. Таким чином, європейська спільнота пропонує до впровадження у правовий простір модель організації судової влади шляхом утворення відповідних органів, які наділяються організаційною та оперативною незалежністю щодо інших гілок влади. До того ж, 34 
визначальним інструментом забезпечення незалежності Вищої ради правосуддя та відповідних судових рад у зарубіжних країнах $€$ закріплення на законодавчому рівні їх правового статусу: або в конституції, або у відповідному законі.

Рекомендація CM/Rec (2010) 12 Комітету міністрів Ради Європи державам-членам щодо суддів: незалежність, ефективність та обов'язки від 17 листопада 2010 року [Електронний ресурс]. - Режим доступу: http://zakon5.rada.gov.ua/laws/show/994_a38 